\title{
Comparison of normal and abnormal labour by using Modified WHO Partograph
}

\section{Manojkumar J. Bhatt, Gunvant K. Kadikar*, Medha Kanani, Shivani Shah}

Department of Obstetrics and Gynecology, Sir T. Hospital and Government Medical College, Bhavnagar, Gujarat, India

Received: 03 January 2018

Revised: 06 March 2018

Accepted: 09 March 2018

\section{*Correspondence:}

Dr. Gunvant K. Kadikar,

E-mail: drgunvant2010@gmail.com

Copyright: (c) the author(s), publisher and licensee Medip Academy. This is an open-access article distributed under the terms of the Creative Commons Attribution Non-Commercial License, which permits unrestricted non-commercial use, distribution, and reproduction in any medium, provided the original work is properly cited.

\section{ABSTRACT}

Background: Modified WHO partograph is graphical record of maternal and foetal data during progress of labour entered against time on single paper sheet. Entire labour can be interpreted in a glance on the photograph. It helps to detect abnormal progress of labour. It guides obstetrician to decide about the need for augmentation of labour or termination of pregnancy either by instrumental delivery or LSCS and avoids prolong labour before obstruction. The objectives were to study the course of normal and abnormal labour and to evaluate the maternal and perinatal outcome in normal and abnormal labour.

Methods: The prospective observational hospital based study of 200 randomly selected cases coming to sir $t$ hospital, bhavnagar for delivery during September 2016 to August 2017 was done. Progress of labour assessed by use of modified WHO partograph. Various parameters like duration of labour, mode of delivery, maternal and neonatal morbidity were studied.

Results: The average duration of active first stage of labour was 4 hrs 38 mins in normal labour and $7 \mathrm{hrs} 48$ mins in abnormal labour. Arrest of descent was responsible for $40 \%$ of abnormal labour. Problems like obstructed labour were avoided by timely intervention in the form of cesarean section and instrumental delivery. Maternal and perinatal outcome were satisfactory.

Conclusions: Routine use of modified WHO partograph helps in early detection of abnormal course in labour. Every women in labour must be benefitted by use of modified WHO partograph for labour monitoring. It assures best maternal and perinatal outcome.

Keywords: Modified WHO partograph, Maternal morbidity, Perinatal morbidity

\section{INTRODUCTION}

Half million women dies every year due to pregnancy related complication. Obstructed labour and ruptured uterus accounts for 70 percent of maternal mortality. ${ }^{1}$ Early detection of abnormal progress of labor and prevention of prolong labor can significantly reduce it. Monitoring of progress of labor thus plays important role in saving women s life. Partograph is an important tool for monitoring progress of labour. E.A.friedman (1954) from USA first popularized the graph, plotting the cervical dilatation against time. ${ }^{2}$ Phillot in 1972 did extensive study in in primi gravid in central and south Africa where he constructed a graph of cervical dilatation against time. He introduce the concept of alert line and action line. The alert line represented as mean rate of progress of the slowest $10 \%$ of patient in African population they served. action line drawn 4 hours to the 
right of the alert line showing that if patient has crossed action line, active management should be instituted within four hours. ${ }^{3}$ This partograph formed the foundation for the WHO model of partograph, which was developed as an international standard in 1988 following the launch of world wide safe motherhood initiative. ${ }^{4}$

Partograph predict deviation from normal labor very early and help in early decision. It has different level of function at different level of health care. It serves as an "early warning system" and assist in early decision on transfer, augmentation and termination of pregnancy. The first WHO partograph covers a latent phase of labor upto 8 hours and an active phase beginning when the cervical dilatation reaches $3 \mathrm{~cm}$. the active phase is provided with an alert line and action line drawn 4 hours apart on the partograph. This partograph is based on the principal that during active labor, the rate of cervical dilatation should not be slower than $1 \mathrm{~cm} /$ hour. A lag time of 4 hours between slowing of labour and need for intervention is enough to make proper decision. Since a prolonged latent phase is relatively infrequent and not usually associate with poor perinatal outcome, usefulness of recording latent phase in partograph has been questioned. So to decrease this disadvantage The WHO modified partograph was introduced by removing the latent phase and considering the beginning of active phase at $4 \mathrm{~cm}$ dilatation of cervix instead of $3 \mathrm{~cm} .{ }^{5}$ In 1969 Hendricks et al demonstrated that in the active phase of normal labor the rate of dilatation of the cervix in primigravida and multigravidae varies little and that there is no deceleration phase at the end of first stage of labor. ${ }^{6}$ In 1973, John stud said that retrospective evaluation of partograph showed that it can separate normal labour from labour destinated to results in an abnormal outcome, such as longer first and second stage, greater incidence of instrumental delivery, and babies with low APGAR score. ${ }^{6}$ Drouin $\mathrm{P}$ conducted a retrospective study of 686 patient and prospective study of 1045 patient at the university center for health science in yaounde, Cameroon, Africa. With the institution of partograph they found that the perinatal mortality decreased by 10 deaths $/ 1000$ births. So, they recommended the use of partograph. ${ }^{8}$ Vaidya et al showed that $99 \%$ of cases delivering before the alert line had normal vaginal delivery and only $1 \%$ of them required forceps application. Of the cases falling outside the alert line $70 \%$ had normal vaginal delivery, $26 \%$ required forceps application and $4 \%$ requires vaccum application. $88 \%$ of cases crosses action line requires interference. ${ }^{8}$ Shortri AN et al in her study observed that $79.9 \%$ primigravidae delivered normal vaginally, $5.7 \%$ required cesarean section before alert line was crossed. Finding suggests that operative intervention increase when labour curve moves to right of the alert line and it increase significantly when as labour curve crosses the action line. ${ }^{10}$ Sizer and Evan found that second stage partograph is associated with increasing chance of spontaneous vaginal delivery for nullipara, decrease chance of instrumental vaginal delivery and emergency cesarean delivery in nulligravidae. ${ }^{11}$ Dangal found that the partograph can be highly effective in reducing complication from prolonged labour for baby and for mother. ${ }^{12}$ Ernst found that there was one uterine rupture and 2 maternal deaths before introduction of partograph but none after partograph introduction. ${ }^{13}$ Javed in found that by using partograph frequency of prolonged and augmented labour, post partum haemorrhage, puerperal sepsis, and perinatal mortality and morbidity reduced. ${ }^{14}$ Windrim reports an increase in cesarean section rate with the use of partograph. ${ }^{15}$ Lavender found no evidence of any difference between partograph and no partograph in cesarean delivery and instrumental delivery. ${ }^{16}$ The emergency caesarean section rate was reduced in W.H.O. modified partograph as compare to latent phas partograph $(8 \% \mathrm{v} / \mathrm{s} 12 \%)$, thus indicating significant reduction in prolonged labour and foetal distress. Also still birth was less in modified partograph as compare to latent phase $0.5 \% \mathrm{v} / \mathrm{s} 2 \%$ ( $\mathrm{P}$ value is $>0.05$ ) indicating an improved maternal and neonatal morbidity. ${ }^{17}$ Khan and Rizvi found that partograph prevented rupture uterus in planned labour after caesarean delivery. ${ }^{18}$

Present study was carried out with following objectives to study the course of normal and abnormal labour, to study various abnormality of active phase of labour, to evaluate maternal outcome in normal and abnormal labour and to evaluate perinatal outcome in normal and abnormal labour.

\section{METHODS}

Present study was a prospective observational study done in the year 2016-17 in Department of Obstetrics and Gynecology, Sir Takhatsinhji hospital, Bhavnagar, India. Study population consist of 200 patients which were randomly selected who were admitted in Gopnath maternity home at Sir T Hospital, Bhavnagar.

\section{Inclusion criteria}

Pregnant women with uncomplicated full term pregnancies (37-40 weeks) with vertex presentation in labour in active phase of labour.

\section{Exclusion criteria}

Women with medical complication like Anemia, Hypertension, Diabetes and Immune compromised status.

Women with obstetrical complication like Preterm labour, Multiple pregnancy, Ante partum hemorrhage, intra uterine growth restriction, pre mature rupture of membrane, intra uterine fetal death.

The prospective observational study will be carried out for the period of one year in government medical college Bhavnagar. 200 cases admitted to labour room will be randomly selected and monitored using modified WHO partograph. All the cases reporting to labour room 
fulfilling the inclusion criteria and suitable for vaginal delivery are included in this study. The course of labour monitored by modified WHO partograph. The cases showing abnormal labour course will re-evaluated by senior obstretician. The decision of operative intervention (instrumental delivery or cesarian section) will be taken by senior obstratician. The new born baby will be managed by neonatologist till their discharge from hospital. Individual partograph will be studied to know the various aspect of course of labour.

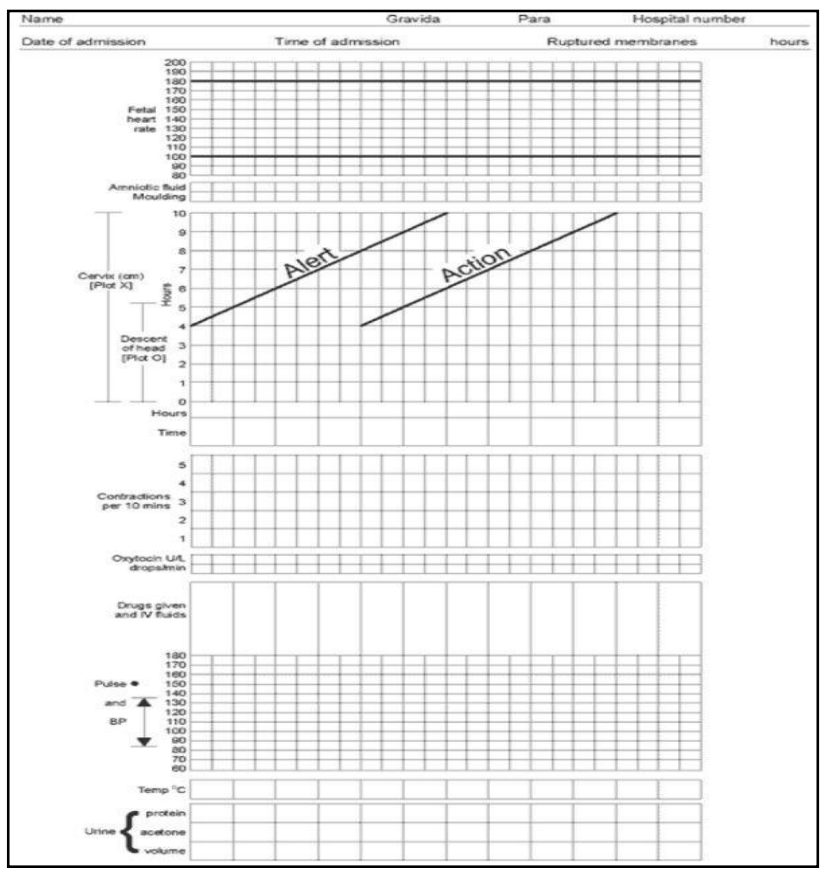

Figure 1: Modified WHO partograph.

\section{RESULTS}

Our hospital is tertiary care hospital. Majority of cases are coming from periphery $\mathrm{CHC}$ and $\mathrm{PHC}$ which comes directly in emergency.

Table 1: Type of admission (N 200).

\begin{tabular}{lll} 
Type of admission & No. of patient & Percentage \\
Emergency & 125 & 62.5 \\
\hline Booked & 75 & 37.5 \\
\hline
\end{tabular}

So, in my study 125 cases $(62.5 \%)$ are emergency cases and remaining $37.5 \%$ are registered. All the patient was examined and include in study randomly who satisfy inclusion criteria.

Table 2: Type of admission (N 200).

\begin{tabular}{|lll|}
\hline Type & No. of patient & Percentage \\
\hline Rural & 156 & 78 \\
\hline Urban & 44 & 22 \\
\hline
\end{tabular}

Our hospital is tertiary care hospital. So, majority cases are coming from rural area 156 (78\%). Remaining 22\% were from urban area.

Table 3: Maternal age distribution.

\begin{tabular}{|lll|}
\hline Age (yrs) & No. of patient & Percentage \\
\hline $18-20$ & 25 & 12.5 \\
\hline $21-25$ & 120 & 60 \\
\hline $26-30$ & 46 & 23 \\
\hline 31 & 09 & 4.5 \\
\hline
\end{tabular}

In present study maximum group of patients observed between 21-25yrs age groups, $60 \%$ cases are of this age group. Minimum patients were from age group $\geq 31 \mathrm{yr}$ responsible for only $4.5 \%$ cases.

Table 4: Distribution according to socio economic status.

\begin{tabular}{|lll|}
\hline Socio economic status & No. of patient & Percentage \\
\hline Lower & 117 & 58.5 \\
\hline Middle & 74 & 37 \\
\hline Upper & 09 & 4.5 \\
\hline
\end{tabular}

In present study majority of cases are from lower socioeconomical status $58.5 \%$. $37 \%$ cases were from middle socioeconomical status while only $4.5 \%$ cases were from higher socioeconomical status.

Table 5: Maternal parity distribution.

\begin{tabular}{lll} 
Parity & No. of patient & Percentage \\
Primigravida & 93 & 46.5 \\
Multigravida & 107 & 53.5 \\
\hline
\end{tabular}

In present study $46.5 \%$ cases are primigravidae while remaining $53.5 \%$ cases are multigravida. According to that both primi and multigravida women composition is almost same in present study.

Table 6: Causes of abnormal labour.

\begin{tabular}{|lll|}
\hline $\begin{array}{l}\text { Cause of abnormal } \\
\text { labour }\end{array}$ & LSCS & $\begin{array}{l}\text { Instrumental } \\
\text { delivery }\end{array}$ \\
\hline Arrest of descent & 04 & 10 \\
\hline Failure of descent & 06 & 04 \\
\hline Protracted descent & 02 & 04 \\
\hline Arrest of dilataion & 03 & 00 \\
\hline Protracted dilatation & 02 & 00 \\
\hline
\end{tabular}

So, most common cause of abnormal labour in present study is arrest of descent of head which is responsible for $40 \%$ of abnormal labour. Out of all abnormal labour $51.43 \%$ (18 cases) delivered by instrumental delivery while $48.57 \%$ (17 cases) required emergency cesarean delivery. Instrumental delivery was not helpful in cases with arrest of dilatation. 
Table 7: Distribution according to birth weight.

\begin{tabular}{|lll|}
\hline Weight & Number of patient & Percentage \\
\hline $2-2.499 \mathrm{~kg}$ & 24 & 12 \\
\hline $2.5-2.999 \mathrm{~kg}$ & 84 & 42 \\
\hline $3-3.499 \mathrm{~kg}$ & 70 & 35 \\
\hline$>3.5 \mathrm{~kg}$ & 22 & 11 \\
\hline
\end{tabular}

So, in present study majority of baby having wt of 2$2.499 \mathrm{~kg}$ responsible for $42 \%$ (84 cases) of all cases. $11 \%$ cases having wt $\geq 3.5 \mathrm{~kg}$ while $12 \%$ cases having wt between $2-2.499 \mathrm{~kg}$ and $35 \%$ cases having wt $3-3.499 \mathrm{~kg}$.

Table 8: Maternal morbidity in case of normal and abnormal labour.

\begin{tabular}{|c|c|c|c|c|}
\hline \multirow[t]{2}{*}{$\begin{array}{l}\text { Maternal } \\
\text { morbidity }\end{array}$} & \multicolumn{2}{|c|}{$\begin{array}{l}\text { Normal labour } \\
(n=165)\end{array}$} & \multicolumn{2}{|c|}{$\begin{array}{l}\text { Abnormal labour } \\
(\mathrm{n}=35)\end{array}$} \\
\hline & No. & Percentage & No. & Percentage \\
\hline $\begin{array}{l}\text { Maternal } \\
\text { fever }\end{array}$ & 2 & 1.21 & 1 & 2.85 \\
\hline $\begin{array}{l}\text { Wound } \\
\text { complication }\end{array}$ & 1 & 0.6 & 2 & 5.71 \\
\hline $\begin{array}{l}\text { PPH, Blood } \\
\text { transfusion }\end{array}$ & 0 & 0 & 1 & 2.85 \\
\hline $\begin{array}{l}\text { Average } \\
\text { duration of } \\
\text { hospital stay }\end{array}$ & $\begin{array}{l}2 \\
\text { days }\end{array}$ & & $\begin{array}{l}6-7 \\
\text { days }\end{array}$ & \\
\hline Total & 3 & 1.81 & 4 & 11.42 \\
\hline
\end{tabular}

So, in present study only 3 mothers with normal labour having some problems. Remaining are healthy which meant that only $1.81 \%$ cases with normal labour develop complication. 4 cases with abnormal labour having problems accounts for $11.42 \%$ morbidity in abnormal labour. Average duration of hospital stays increase in case of abnormal labour. Wound complication was most common morbidity in abnormal labour accounting for $5.71 \%$ which was only $0.6 \%$ in normal labour. Average duration of hospital stays also increased in cases with abnormal labour.

Table 9: Neonatal morbidity in cases with normal and abnormal labour.

\begin{tabular}{|lllll|}
\hline $\begin{array}{l}\text { Neonatal } \\
\text { morbidity }\end{array}$ & \multicolumn{2}{l}{$\begin{array}{l}\text { Normal labour } \\
\text { Total 165 }\end{array}$} & \multicolumn{2}{l|}{$\begin{array}{l}\text { A bnormal } \\
\text { labour, Total 35 }\end{array}$} \\
\hline $\begin{array}{l}\text { No. } \\
\text { Birth asphyxia }\end{array}$ & 3 & Percent & No. & Percent \\
\hline $\begin{array}{l}\text { Ophthalmic } \\
\text { infection }\end{array}$ & 3 & 1.81 & 3 & 8.57 \\
\hline $\begin{array}{l}\text { Meconium } \\
\text { aspiration } \\
\text { syndrome }\end{array}$ & 1 & 0.6 & 3 & 8.57 \\
\hline Jaundice & 1 & 0.6 & 5 & 0 \\
\hline $\begin{array}{l}\text { Average } \\
\begin{array}{l}\text { Duration of } \\
\text { NICU stay }\end{array}\end{array}$ & $2-3$ & & $3-4$ & \\
\hline Neonatal death & 0 & 0 & 0 & 0 \\
\hline Total & 8 & $4.84 \%$ & 11 & $31.42 \%$ \\
\hline
\end{tabular}

$1.81 \%$ babies with abnormal labour develop birth asphyxia, while $8.57 \%$ babies with abnormal labour labor develop birth asphyxia. $1.81 \%$ babies with normal labour develop ophthalmic infection, while no ophthalmic infection occur in babies with abnormal labor. $0.6 \%$ babies with normal labor develop meconium aspiration syndrome, while $8.57 \%$ babies with abnormal labor develop meconium aspiration syndrome.

$0.6 \%$ babies with normal labor develop jaundice, while $14.28 \%$ babies with abnormal labor develop jaundice. So, 8 out of 165 normal delivery babies kept in NICU. Accounts for $4.84 \%$ NICU admission in normal labour. 11 out of 35 babies with abnormal labour kept in NICU, accounts for $31.42 \%$ NICU admission in abnormal labour.

Table 10: Modes of delivery with relation to action and alert line.

\begin{tabular}{|c|c|c|c|}
\hline Groups & $\begin{array}{l}\text { Normal } \\
\text { delivery }\end{array}$ & LSCS & $\begin{array}{l}\text { Instrumental } \\
\text { delivery }\end{array}$ \\
\hline $\begin{array}{l}\text { Group } 1 \text { (before } \\
\text { alert line) }\end{array}$ & $\begin{array}{l}148 \\
(98.6 \%)\end{array}$ & $\begin{array}{l}02 \\
(1.3 \%)\end{array}$ & $02(1.3 \%)$ \\
\hline $\begin{array}{l}\text { Group } 2 \\
\text { (between alert } \\
\text { and action line) }\end{array}$ & $\begin{array}{l}15 \\
(55.5 \%)\end{array}$ & $\begin{array}{l}03 \\
(11.1 \%)\end{array}$ & $09(33.3 \%)$ \\
\hline \multirow[t]{2}{*}{$\begin{array}{l}\text { Group } 3 \text { (after } \\
\text { action line) }\end{array}$} & $\begin{array}{l}02 \\
(9.5 \%)\end{array}$ & $\begin{array}{l}12 \\
(57.1 \%)\end{array}$ & $07(33.3 \%)$ \\
\hline & 165 & 17 & 18 \\
\hline
\end{tabular}

Majority of cases before alert line delivered by spontaneous vaginal delivery 148 out of 152 (98.6\%). Cases crossing the action line either required instrumental delivery $07(33.3 \%)$ or required LSCS 12 (57.1\%). Only 2 cases who crossed the action line delivered normally $9.5 \%$. Total 17 out of 200 required cesarean delivery (8.5\% cases) while 18 out of 200 (9\% cases) required instrumental delivery.

Table 11: Average duration of stages of labour.

\begin{tabular}{|lll|}
\hline $\begin{array}{l}\text { Stages of } \\
\text { labour }\end{array}$ & $\begin{array}{l}\text { Normal labour } \\
\text { Mean } \pm \text { S.D }\end{array}$ & $\begin{array}{l}\text { Abnormal labour } \\
\text { Mean } \pm \text { S.D }\end{array}$ \\
\hline $1^{\text {st }}$ stage & $\begin{array}{l}4 \mathrm{hr} 38 \min \pm 1 \mathrm{hr} \\
20 \mathrm{mins}\end{array}$ & $\begin{array}{l}7 \mathrm{hr} 48 \mathrm{mins} \pm 2 \mathrm{hrs} \\
47 \mathrm{mins}\end{array}$ \\
\hline $2^{\text {nd }}$ stage & $\begin{array}{l}37.26 \mathrm{mins} \pm 14 \\
\text { mins }\end{array}$ & 86 mins \pm 49 mins \\
\hline
\end{tabular}

So, average duration of first stage of labour in normal labour was $4 \mathrm{hrs} 38 \mathrm{mins} \pm 1 \mathrm{hr} 20 \mathrm{mins}$ while average duration of first stage of labour in abnormal labour was $7 \mathrm{hr} 48$ mins \pm 2 hrs 47 mins.

Average duration of $2^{\text {nd }}$ stage of labour in normal labour was $37.26 \mathrm{mins} \pm 14$ mins, while Average duration of 2 nd stage of labour in abnormal labour was 86 mins \pm 49 mins. So, average duration of first and second stage of labour increased in abnormal labour. 
Table 12: Comparison of various study of in mode of delivery in relation to action and alert line.

\begin{tabular}{|c|c|c|c|c|c|c|c|c|c|}
\hline & \multicolumn{3}{|c|}{ Group 1} & \multicolumn{3}{|c|}{ Group 2} & \multicolumn{3}{|c|}{ Group 3} \\
\hline & ND & Ins. D & LSCS & ND & Ins. D & LSCS & ND & Ins. D & LSCS \\
\hline Freidman's study ${ }^{19}$ & $92.3 \%$ & $1.5 \%$ & $6.2 \%$ & $61.9 \%$ & $4.7 \%$ & $33.3 \%$ & $21.4 \%$ & $7.1 \%$ & $71.4 \%$ \\
\hline Shinde et $\mathrm{al}^{20}$ & $96.2 \%$ & $12 \%$ & $2.8 \%$ & $58.3 \%$ & $25 \%$ & $16.7 \%$ & $14.3 \%$ & 0 & $85.7 \%$ \\
\hline Javed et $\mathrm{al}^{14}$ & $88 \%$ & $5.6 \%$ & $6.4 \%$ & $72.4 \%$ & $13.8 \%$ & $13.8 \%$ & $18 \%$ & $45.6 \%$ & $36.4 \%$ \\
\hline Present study & $98.6 \%$ & $1.3 \%$ & $1.3 \%$ & $55.5 \%$ & $11.1 \%$ & $33.3 \%$ & $9.5 \%$ & $57.14 \%$ & $33.3 \%$ \\
\hline
\end{tabular}

Group 1: Befor alert line; Group 2: Between action and alert line; Group 3: After action line

In present study, $98.6 \%$ cases (148) before alert line (Group 1) having normal delivery which is comparable with Shinde et al (96.2) and Freidman (92.3\%). ${ }^{19}$ In present study $1.3 \%$ cases (2 cases) before alert line (group 1) required instrumental delivery which is comparable with Freidman's study $(1.5 \%) .{ }^{19}$ In present study, $1.3 \%$ cases (2 cases) before alert line (group 1) required EMLSCS which is comparable with shined et al $(2.8 \%)$. In present study, $55.5 \%$ cases between action and alert line (group 2) having normal delivery which is comparable with Shine et al (58.5\%)and Friedman's study $(61.9 \%) .{ }^{20}$ In present study $11.1 \%$ cases between action and alert line (group 2) required instrumental delivery which is comparable with Javed et al (13.8\%). ${ }^{14}$ In present study $33.3 \%$ cases between action and alert line (group 2) required EMLSCS which is comparable with Friedman's study (33.3\%). In present study $9.5 \%$ cases after action line (group 3) having normal delivery which is comparable with Shinde et al (14.3\%). In present study $57.14 \%$ case after action line (group 3) required instrumental delivery which is comparable with Javed et al $(45.6 \%)$. In present study $33.3 \%$ case after action line (group 3) required instrumental EMLSCS which is comparable with Javed et al (36.4\%)

\section{DISCUSSION}

In present study, $37.5 \%$ cases were registered for routine antenatal check up while $62.5 \%$ cases are referred or direct cases. In present study, $78 \%$ cases were from rural area suggesting increase awareness regarding ANC examination and institutional delivery in rural area. Maximum number of patients $(60 \%)$ in this study belongs to $21-25$ yrs of age groups. $58.5 \%$ cases belong to lower socioeconomical class, $37 \%$ belongs to middle socioeconomical class while $4.5 \%$ cases belong to upper socioeconomical class. $46.5 \%$ case were primigravida while $53.5 \%$ cases were multigravida. Maximum distribution of baby wt was $2.5-2.999 \mathrm{~kg}(42 \%)$ compared to other wt range. In present study $82.5 \%$ cases delivered vaginally, $8.5 \%$ cases required LSCS while $9 \%$ cases required instrumental delivery. Most common cause of abnormal labour in present study is arrest of descent of head which is responsible for $40 \%$ of abnormal labour. Instrumental delivery is not helpful in cases with arrest of dilatation and protracted dilatation. Out of all abnormal labour $51.43 \%$ (18 cases) delivered by instrumental delivery while $48.57 \%$ (17 cases) required emergency cesarean delivery. Protracted dilatation was responsible for $5.71 \%$ of abnormal labour in present study. In present study 2 cases $(1.21 \%)$ with normal labour develop post partum fever and 1 case $(60 \%)$ develop wound complication. So, only $1.81 \%$ cases with normal labour develop complication. 1 case with abnormal labour develop post partum fever, 2 cases with abnormal labour develop wound complication and 1 case with abnormal labour develop PPH and required blood transfusion. So, there is $11.42 \%$ morbidity in abnormal labour. Average duration of hospital stays increase in case of abnormal labour. In present study, 8 out of 165 normal delivery babies kept in NICU. Accounts for $4.84 \%$ NICU admission in normal labour. 11 out of 35 babies with abnormal labour kept in NICU, accounts for $31.42 \%$ NICU admission in abnormal labour. There was no any neonatal or maternal death in present study. Average duration of first and second stage of labour increased in abnormal labour compared to normal labour. Average duration of NICU stay is more in cases with abnormal labour. Total 19 out of 200 cases required NICU admission responsible for $9.5 \%$ NICU admission. In present study Majority of cases before alert line delivered by spontaneous vaginal delivery 148 out of 152 (98.6\%). Cases crossing the action line required instrumental delivery $07(33.3 \%)$ and LSCS $12(57.1 \%)$. Only 2 cases who crossed the action line delivered normal vaginally 9.5\%. In present study, $98.6 \%$ cases (148) before alert line (Group 1) having normal delivery which is comparable with Shinde et al (96.2) and Freidman $(92.3 \%)$. In present study $1.3 \%$ cases ( 2 cases) before alert line (group 1) required instrumental delivery which is comparable with Freidman's study $(1.5 \%)$. In present study, $1.3 \%$ cases ( 2 cases) before alert line (group 1) required EMLSCS which is comparable with Shinde et al $(2.8 \%)$. In present study, $55.5 \%$ cases between action and alert line (group 2) having normal delivery which is comparable with Shinde et al $(58.5 \%)$ and Friedman's study $(61.9 \%)$. In present study $11.1 \%$ cases between action and alert line (group 2) required instrumental delivery which is comparable with Javed et al (13.8\%). In present study $33.3 \%$ cases between action and alert line (group 2) required EMLSCS which is comparable with Friedman's study $(33.3 \%) .{ }^{19}$ In present study $9.5 \%$ cases after action line (group 3) having normal delivery which is comparable with Shinde et al $(14.3 \%) .{ }^{20}$ In present study $57.14 \%$ case after action line (group 3) required instrumental delivery which is comparable with Javed et 
al $(45.6 \%)$. In present study $33.3 \%$ case after action line (group 3) required instrumental EMLSCS which is comparable with Javed et al $(36.4 \%) .{ }^{14}$

\section{CONCLUSION}

Partograph was initially used for early warning system to detect labour that was not progressing normally. This would allow for timely transfer to occur to a referrel center for augmentation or caesarean section as required. The Partograph Indicates when augmentation is needed and can point to possible CPD before labour becomes obstructed. It increases the quality and regularity of observation made on mother and fetus and it also serves as a one page visual summary of relevant details of labour. The partograph has been used in number of countries and has been shown to be effective in preventing prolonged labour, in reducing operative intervention and in improving the neonatal outcome. The safe motherhood initiative emphasizes that the partographic monitoring of labour for early detection of abnormal labour is one of the most important approach for reducing maternal and neonatal morbidity. From observation of present study, we conclude that routine use of modified WHO partograph during labour management helps in early detection of abnormal labour, guiding in timely intervention leading to avoidance of problem of prolong labour and its complication. It assures the best maternal and fetal outcome. So, it is suggested that intrapartum monitoring by modified WHO partograph is an important tool in monitoring the progress of labour in PHCS, CHCS and all institutions. Every woman in labour must be benefited by modified WHO partograph.

Funding: No funding sources Conflict of interest: None declared

Ethical approval: The study was approved by the Institutional Ethics Committee

\section{REFERENCES}

1. Maternal Mortality Rates. A Tabulation of Available Information, WHO document FHE/86-3, $2^{\text {nd }} \mathrm{Ed}$, 1996.

2. Friedman E. The graphical analysis of labour. Am J Obset Gynecol. 1954:68:1568-75.

3. Philpott RH, Castle WM. Cervicographs in the management of labour in Primigravidae. Int $\mathrm{J}$ Gynecol Obstet. 1972 July;79(7):592-8.

4. WHO partograph cuts complications of labor and childbirth. Safe Mother. 1994;(15):10.

5. Mathews JE, Rajaratnam A, George A, Mathai M. Comparison of two World Health Organization
(WHO) partographs. Int J Gynecol Obstet. 2007 Feb;96(2):147-150.

6. Hendricks, CH, Brenner, WE, Kraus, G. Normal cervical dilatation pattern in late pregnancy and labour. Am J Obstet Gynecol. 1970; 106(8):1065-82.

7. Studd J. Partograms and Nomograms of Cervical Dilatation in Management of Primigravid Labour. BMJ. 1973 Nov;4(5890):451-5.

8. Drouin B, Nasah BT, Nkounawa F. The value of the partogram in the management of labour. Qbstet Gynaecol. 1979;53(6):741-5.

9. Vaidya PR, Patkar LV. Monitoring of labour by partogram. J Obstet Gnnecol. 1985:41(3)

10. Shrotri AN. Early recognition of abnormal labour in primi gravidae. J Obset Gynecol India. 1991:41(3).

11. Sizer AR, Evans J, Bailey SM, Wiener J. A secondstage partogram. Obstet Gynecol. 2000;96(5):67883.

12. Dangal G. Preventing prolonged labor by using partogram. Int J Gynecol Obstet. 2007;7(1).

13. Orji EO, Fatusi AA, Makinde NO, Adeyemi AB, Onwudiegwu U. Impact of training on the use of partograph on maternal and perinatal outcome in peripheral health centers. J Turkish-German Gynecol Assoc. 2007;8(2):344-7.

14. Iffat J, Shereen B, Tabassum S. Role of partogram in preventing prolonged labor. J Pakistan Med Assoc. 2007 Aug;57(8):408-11.

15. Windrim R, Seaward PG, Hodnett E, Akoury H. A randomized controlled trial of a bedside partogram in the active management of primiparous labour. J Gynecol Obstet Canada. 2007 Jan; 29(1):27-34.

16. Lavender T, Hart A, Smyth RM. Effect of partogram use on outcomes for women in spontaneous labor at term. Cochrane database system rev 2008 Oct;60(4):CD005461.

17. Meena R, Gangwal M, Agarwal S, Bairwa R, Meena M, Meena A. Outcome of labour monitored by W.H.O. modified partograph and latent phase partograph. BMR Med. 2016;3(1):1-7

18. Khan KS, Rizvi A. The partograph in the management of labor following Cesarean section. Int J Gynecol Obstet. 1995;50(2):151-7.

19. Wayne R, Friedman, Emanuel A. Labor: clinical evaluation and management. New York, AppletonCentury Crofts;1978:2.

20. Shinde KJ, Bangal V, Singh RK. study of course of labour by modified WHO partograph. IJBAR. 2012;03:05.

Cite this article as: Bhatt MJ, Kadikar GK, Kanani M, Shah S. Comparison of normal and abnormal labour by using Modified WHO Partograph. Int J Reprod Contracept Obstet Gynecol 2018;7:1440-5. 